\title{
Therapeutic Potential of Mesenchymal Stem Cells vs. Estradiol Benzoate or Avosoya on the Cerebellar Cortex of Ovariectomized Adult Albino Rats
}

Samah M Ahmed ${ }^{1 *}$, Shaimaa A Abdelrahman ${ }^{1}$ and Sally M Shalaby ${ }^{2}$

${ }^{1}$ Department of Histology and Cell Biology, Faculty of Medicine, Zagazig University, Zagazig, Egypt

${ }^{2}$ Department of Medical Biochemistry, Faculty of Medicine, Zagazig University, Zagazig, Egypt

\begin{abstract}
Alterations in hormone levels during menopause affect cognitive function and brain chemistry. Stem cell therapy in nervous system disorders is a growing field. The present research aimed to compare the effect of MSCs with that of estradiol benzoate or avosoya on the cerebellum of ovariectomized rats. Fifty eight adult female Wistar albino rats were classified into five groups. Control group (Group I) and four ovariectomized groups. Group II (ovariectomized rats received no treatment), Group III (injected subcutaneously with estradiol benzoate), Group IV (received avosoya orally) and Group V (treated with human umbilical cord blood derived mesenchymal stem cells [HUCBMSCs]). Cerebellar sections were stained with hematoxylin and eosin and cresyl fast violet. Immunoperoxidase reaction of glial fibrillary acidic protein (GFAP), estrogen receptor beta $(\operatorname{Er} \beta)$ and Bax protein was also done. HUCBMSCs homing in rat cerebellum were detected by human albumin gene. Antioxidant enzyme levels were also measured in cerebellum homogenate. Decreased density of neurons in the three cortical layers with vacuolations and distorted Purkinje cells with pyknotic nuclei were observed in Group II. Group III cerebellar cortex showed normal architecture but some Purkinje cells had pyknotic nuclei. Group IV showed normal neuronal cells in the three cortical layers. Group V Purkinje cells were pyriform with vesicular nuclei, and basophilic cytoplasm. Small rounded cells with deeply stained nuclei appeared in the granular layer. In conclusion: estradiol benzoate and avosoya improve ovariectomy-induced cerebellar alteration, and MSCs show promising results in this field.
\end{abstract}

Keywords: Ovariectomy; Cerebellum; Estradiol benzoate; Avosoya; Mesenchymal stem cells

Abbreviations: Era: Estrogen Receptor Alpha; Er $\beta$ : Estrogen Receptor Beta; HRT: Hormone Replacement Therapy; MSCs: Mesenchymal Stem Cells; OVX: Ovariectomy; GFAP: Glial Fibrillary Acidic Protein; HUCB: Human Umblical Cord Blood; MNCs: Mononuclear Cells; EDTA: Ethylene di-amine tetra Acetic acid; SOD: Superoxide Dismutase; CAT: Catalase; GSH: Reduced Glutathione; BDNF: Brain-derived Neurotrophic Factor; NO: Nitric Oxide; HUCBMCs: Human Umbilical Cord Blood derived Mesenchymal Stem Cells

\section{Introduction}

Cerebellum has a significant role in motor control, cognitive functions as attention, language and regulating pleasure or fear responses. It does not initiate movement, it contributes to coordination, precision and accurate timing. It receives input from sensory systems of the spinal cord and from other regions of the brain and integrates them to fine tune motor activity. Patients suffered from cerebellar damage have disorders in fine movement, equilibrium, posture and motor learning $[1,2]$.

Estrogens guide cerebellar development. Cerebellum itself may be a source of estradiol through local steroid hormone synthesis as estradiol uptake was also observed in cerebellum. So, the cerebellum is considered as a target of estrogen action [3]. The adult cerebellum expresses both estrogen receptor alpha (Era) and $\operatorname{Er} \beta$ [4]. Era expression in adults is localized primarily to granule cells, but at low concentrations [5]. In contrast, the adult cerebellum expresses high levels of $\operatorname{Er} \beta$, primarily in Purkinje cells and also in cerebellar granule cells [6].

In ovariectomized rats and postmenopausal women, hormone replacement therapy (HRT) with estrogen was applied to relieve vasomotor symptoms. It has also been reported that estrogen replacement therapy improves learning and memory function of the brain [7]. Despite the beneficial role of HRT regarding the management of menopausal symptoms yet, side effects such as irregular bleeding, breast tenderness, mastalgia and risk of breast cancer after long term exposure to HRT can occur. These drawbacks produce poor compliance of the HRT and motivate wide interests in searching for alternative compounds $[7,8]$.

Phytoestrogens represent a heterogeneous group of herbal substances; their structure is similar to $17-\beta$-estradiol. They are called estrogen-like molecules or non-steroidal estrogens. In spite of the structural similarity with estradiol, phytoestrogens are diphenolic yet non-steroidal compounds [9]. They are naturally found in some vegetables, fruits, cereals, and beans. Genistein, daidzein and glycitein belong to the class of isoflavones and are known to have the most powerful estrogenic action. They are found largely in soybeans and their byproducts [10]. These natural phytoestrogens have estrogenic characteristics and are able to bind estrogen receptors that lead to their agonist-antagonist characteristics depending on different target tissues [11].

MSCs are non-hematopoietic multi-potent stem cells that have the ability for self-renewal and multi-lineage differentiation. These cells were first described as residing in the bone marrow (BM), however,

*Corresponding author: Samah M Ahmed, Lecturer of Histology and Cell Biology Faculty of Medicine, Zagazig University, Zagazig, Egypt, Tel: 00201006427658 E-mail: dr_samah_m@yahoo.com

Received December 20, 2016; Accepted March 10, 2017; Published March 20, 2017

Citation: Ahmed SM, Abdelrahman SA, Shalaby SM (2017) Therapeutic Potential of Mesenchymal Stem Cells vs. Estradiol Benzoate or Avosoya on the Cerebellar Cortex of Ovariectomized Adult Albino Rats. J Cytol Histol 8: 444. doi: 10.4172/2157-7099.1000444

Copyright: (C) 2017 Ahmed SM, et al. This is an open-access article distributed under the terms of the Creative Commons Attribution License, which permits unrestricted use, distribution, and reproduction in any medium, provided the original author and source are credited. 
MSCs have also been successfully isolated from tissues other than BM (e.g., umbilical cord blood, placenta, amniotic fluid, adipose tissue, lung, skeletal muscle and the dental pulp) [12]. Human MSCs play an essential role in today's medical research. They provide promising approaches in the treatment of human diseases. Their plasticity and proliferation potential make them an important tool for cell transplantation as well as generation of living, functional tissue suitable for organ repair and replacement [13]. MSCs are promising in cell therapies as they are easily obtained from various tissues and have the properties of tissue repair and revascularization [14].

Human MSCs have the ability to self-renew and differentiate into adipogenic, osteogenic, and chondrogenic lineage, producing tissues such as bone, cartilage, tendon, adipose tissue, and hematopoietic supporting stroma [15].

MSCs lack expression of hematopoietic markers as $\mathrm{CD}_{19}, \mathrm{CD}_{45}$, $\mathrm{CD}_{34}$ or HLA-DR and show positivity for $\mathrm{CD}_{73}, \mathrm{CD}_{90}$ and $\mathrm{CD}_{105}$ [16]. $\mathrm{CD}_{105}$ (Endoglin) is a membrane glycoprotein and part of the transforming growth factor- $\beta$ receptor complex. It plays an important role in angiogenesis $[17,18]$. MSCs exert their effects through their antioxidant properties. MSCs exhibited antioxidant activity through the effect on the levels of glutathione, and superoxide dismutase, and modulating the pathways of antioxidant-related protein activation $[19,20]$. Furthermore, Kim et al. [21] suggested that early intravenous injection of MSCs after acute spinal cord injury may prevent further damage through enhancement of antioxidative mechanisms, without inducing adverse effects. So, the main objective of this study was to evaluate the effect of estrogen deprivation on the structure of the cerebellar cortex of ovariectomized rats and to compare the possible ameliorative effects of MSCs $v s$. estradiol benzoate or avosoya.

\section{Materials and Methods}

\section{Chemicals}

- Povidone-iodine: Antiseptic solution (B- SEPT), from SAGA PHARMA, Egypt.

- Benzyl penicillin: In the form of vials containing 1000000 IU Penicillin G, purchased from Misr Company for Pharmaceuticals Industry, Egypt. The vial was dissolved for intramuscular injection using ampoules containing $5 \mathrm{~mL}$ sterile water for injection from Egypt Otsuka Pharm Co., Egypt.

- $\quad$ Estradiol Benzoate: In the form of ampoules; each contains estradiol benzoate $5 \mathrm{mg}$. (Folone) purchased from Misr Company for Pharmaceuticals Industry, Egypt. Estradiol benzoate was dissolved in sesame oil to obtain a dose of $5 \mu \mathrm{g}$ of estradiol benzoate in $0.1 \mathrm{~mL}$ sesame oil.

- Avosoya: In the form of hard gelatinous capsules containing avocado/soybean unsaponifiables (ASU) extract $300 \mathrm{mg}$ providing avocado oil $100 \mathrm{mg}$ and soybean oil $200 \mathrm{mg}$. It was purchased from Trend Pharm, Egypt. It was dissolved in distilled water and given orally by gavage once a day at a dose of $10 \mathrm{mg} / \mathrm{kg}$ per day.

- Dulbecco's modified Eagle’s medium (DMEM, GIBCO/BRL).

- $10 \%$ fetal bovine serum (FBS, GIBCO/BRL).

- Density gradient [Ficoll/Paque (Pharmacia)].

- $\quad$ Complete culture medium supplemented with $1 \%$ penicillinStreptomycin (GIBCO/BRL).

- $\quad 0.25 \%$ trypsin in $1 \mathrm{mM}$ EDTA (GIBCO/BRL).
- $\quad$ Phosphate buffer saline (PBS) (GIBCO/BRL).

- Trypan blue dye (Sigma)

- $\quad$ Paul Karl Horan 26 (PKH-26) (red fluorescence cell linker) (Sigma, cat.\# MINI26).

\section{Animals}

Fifty eight adult healthy female Wistar albino rats (3-5 months) weighing 200-250 g were utilized in this study. The rats were obtained from the Animal House, Faculty of Medicine, Zagazig University, Zagazig, Egypt. They were kept under controlled laboratory conditions; housed at room temperature $\left(20 \pm 2^{\circ} \mathrm{C}\right)$, fed standard balanced diet (20\% protein diet composed of: yellow corn 670 g, peanuts 200 $\mathrm{g}$, vitamin mix $100 \mathrm{~g}$, molasses $20 \mathrm{~g}$ and sodium chloride $10 \mathrm{~g}$ ) and allowed water ad libitum [22]. All animals were cared in accordance with the guidelines for animal research issued by the National Institute of Health and was approved by Animal Ethics Committee, Zagazig University, Zagazig, Egypt.

\section{Ovariectomy procedure}

After two weeks of acclimatization, the rats were anaesthetized by intraperitoneal injection of $25 \mathrm{mg} / \mathrm{kg}$ sodium thiopental [23]. They were subjected to ovariectomy (OVX) operation. The lower part of the back was shaved and a single 1.5 to $2 \mathrm{~cm}$ incision was made in the skin to expose the back muscles. $2 \mathrm{~cm}$ incision was made in the muscles overlying the ovaries on both sides, and the ovaries were isolated, tied off with sterile suture and removed. The muscles and the skin were sutured separately. To prevent wound damage from other animals, they were caged separately for post-surgical care [24]. The surgical wound of the operated rats was cleaned with povidone iodine twice a day for 5 days. Rats were also administered benzyl penicillin $40000 \mathrm{U} /$ $\mathrm{kg}$ intramuscular for 7 days [25]. Rats in the sham- ovariectomy group received the fake operation, removal of a small piece of fat (the volume of fat was equal to the removed tissue in OVX rats), with preservation of both ovaries [26].

Isolation of mesenchymal stem cells (MSCs) from human umbilical cord blood (HUCB): With informed consent, mononuclear cells (MNCs) from HUCB were collected from full term delivery women at Zagazig University Hospital. After complete separation of the placenta, cord blood was collected under strict aseptic conditions. Cord blood was directly drawn into a $50 \mathrm{~mL}$ tube containing $5 \mathrm{~mL}$ of phosphate buffer saline (PBS) pH 7.2 and 2 mM EDTA. Cord blood was then diluted $3 \mathrm{X}$ with PBS buffer. The mononuclear cell fraction was isolated by loading $30 \mathrm{~mL}$ of whole blood onto $10 \mathrm{~mL}$ of Ficoll/Paque (Lymphocyte Separation Medium 1.077, Lonza Bioproducts) in $50 \mathrm{~mL}$ tubes, then, centrifuged for $30 \mathrm{~min}$ at $20^{\circ} \mathrm{C}$. Interphase MNCs layer was collected after aspirating and discarding the supernatant. The cells were washed with $20 \mathrm{~mL}$ PBS and centrifuged at room temperature. The supernatant was aspirated and the cells were washed with PBS a second time. MNCs were subcultured with culture medium [low glucose Dulbecco's Modified Eagle's Medium (DMEM 1.0 g/L glucose Lonza Bioproducts, Belgium) and 10\% fetal bovine serum (FBS, Lonza Bioproducts, Belgium)]. Cells were incubated at $37^{\circ} \mathrm{C}$ in $5 \%$ humidified $\mathrm{CO}_{2}$ in $\mathrm{CO}_{2}$ incubator (Heraeus, Germany). Non-adherent cells were eliminated by a half medium change at 1,2, and 3 days and the whole medium was replaced with fresh medium every week. The cells were grown for 2-3 weeks until $80-90 \%$ confluence. The whole adherent cells were then detached by trypsinization with $0.25 \%$ trypsin/ ethylene diamine tetra acetic acid (EDTA) (Trypsin 1:250, EDTA $1 \mathrm{mM}$, LonzaBioproducts, Belgium) [27]. 
Real time PCR for characterization of HUCB-MSCs: Total RNA was extracted from cell culture by RNA extraction kit (Qiagen Ltd., Crawley, West Sussex, UK) then reverse transcribed by QuantiTect Reverse Transcription Kit (Qiagen, Germany). The primers used as follows:

$$
\begin{aligned}
& \mathrm{CD}_{34} \text { sense 5'- AATGAGGCCACAACAAACATC ACA-3' } \\
& \mathrm{CD}_{34} \text { antisense 5'-CTGTCCTTCTTAACCTCCGCACAGC-3' } \\
& \mathrm{CD}_{105} \text { sense 5'-CTTGGCCTACAATTCCAGCC-3' } \\
& \mathrm{CD}_{105} \text { antisense 5'-CTTGAGGTGTGTCTGGGAGC-3' }
\end{aligned}
$$

GAPDH (reference gene) sense 5'- CTG ATGCCCCCATGTTCGTC-3' $[28,29]$

GAPDH antisense 5'-CACCCTGTTGCTGTAGCCAAATTCG-3'

The converted cDNA samples were amplified by real-time PCR (Applied Biosystems) at a final volume of $20 \mu \mathrm{L}$ using SYBR Green Master Mix (Applied Biosystems). Melting curve analysis was performed using Dissociation Curves software (Applied Biosystems) to ensure that only a single product was amplified.

Labeling of HUCB-MSCs with cell linker Paul Karl Horan 26 (PKH-26) (red fluorescence): HUCB-MSCs were harvested during the $2^{\text {nd }}$ passage and were labelled with $\mathrm{PKH} 26$ dye [30]. Cells were centrifuged and washed twice in serum free medium. Cells were pelleted and suspended in the dye solution.

Injection of HUCB-MSCs into the rat: Formed colonies of the $2^{\text {nd }}$ generation were washed twice with PBS and cells were trypsinized with $0.25 \%$ trypsin in $1 \mathrm{mM}$ EDTA for $5 \mathrm{~min}$ at $37^{\circ} \mathrm{C}$. After centrifugation at $2400 \mathrm{RPM}$ for $20 \mathrm{~min}$. Cells were counted under microscope by using haemocytometer and calculated. MSCs $\left(4.5 \times 10^{6}\right.$ cells in $250 \mu \mathrm{L}$ PBS $)$, were injected into the tail vein of HUCB-MSCs treated group [31].

Detection of HUCB-derived MSCs homing by fluorescent microscope: Sections of cerebellar cortex of stem cell treated group showed PKH26 labelled stem cells appearing as bright dots. They were examined by fluorescent microscope (Olympus BX50F4, No. 7M03285, Tokyo, Japan), Medical Biochemistry Department, Faculty of medicine, Zagazig University, Zagazig, Egypt.

Detection of HUCB-derived MSCs homing in rat cerebellum: Homing of HUCB-derived MSCs was confirmed by PCR detection of the human albumin gene in rat cerebellum. Amplification of the human albumin gene; the housekeeping gene was performed by using forward primers: 5'-CCAGGAAGACATCCTTTGC-3' and reverse primer 5'- CCTGAGCCAGAGATTTCC-3'. Genomic DNA was isolated from rat cerebellum using the TIANamp Genomic DNA isolation kit (TIANGEN, Beijing, China). PCR was carried out in a final volume of $25 \mu \mathrm{L}$ containing $2 \mu \mathrm{L}(30 \mathrm{mg})$ of genomic DNA, 0.2 $\mu \mathrm{mol} / \mathrm{L}$ of each primer and $10 \mathrm{~mL}$ of Taq PCR Master Mix (BIORON). The amplification protocol was as follows: $94^{\circ} \mathrm{C}$ for $10 \mathrm{~min}$, then 35 cycles of $94^{\circ} \mathrm{C}$ for $1 \mathrm{~min}, 56^{\circ} \mathrm{C}$ for $45 \mathrm{~s}$ and $72^{\circ} \mathrm{C}$ for $45 \mathrm{~s}$; then $72^{\circ} \mathrm{C}$ for 7 min, using the heated lid thermal cycler. PCR products ( $329 \mathrm{bp}$ ) were separated with the use of $2 \%$ agarose gel electrophoresis [32].

\section{Experimental procedure}

The animals were assigned to:

Group I (control group) included 18 rats that equally subdivided into three subgroups:
- Subgroup 1: (Sham-ovariectomy group): Rats were subjected to fake operative intervention [26].

- Subgroup 2: Each rat received sesame oil at a dose of $0.1 \mathrm{~mL} /$ day subcutaneously.

- Subgroup 3: Each rat received $250 \mu \mathrm{L}$ PBS was injected into the tail vein.

Group II: Ten ovariectomized rats were left without treatment [24].

Group III: Ten ovariectomized rats injected subcutaneously with $5 \mu \mathrm{g}$ estradiol benzoate dissolved in $0.1 \mathrm{~mL}$ sesame oil/ day for 8 weeks from the second day after operation [33].

Group IV: Ten ovariectomized rats administered avocado/soybean unsaponifiables (ASU) (Avosoya ${ }^{\mathrm{Tx}}$; Trend Pharm, Egypt) dissolved in distilled water and given orally by gavage once a day at a dose of $10 \mathrm{mg} /$ $\mathrm{kg}$ per day for 8 weeks from the second day after operation. The dose was established based on the recent FDA guidelines [34].

Group V: Ten ovariectomized rats treated with HUCB-MSCs at the second day after ovariectomy operation $\left(4.5 \times 10^{6}\right.$ cells in $250 \mu \mathrm{L}$ PBS). The cells were injected into the tail vein [31].

\section{Survival of animals}

No death was reported in the rats of the control or other groups.

\section{Histological study}

At the end of the experiment, the rats from all groups were fasted overnight. They were sacrificed 8 weeks from the second day after ovariectomy operation with intraperitoneal injection of $25 \mathrm{mg} /$ $\mathrm{kg}$ sodium thiopental [23]. The cerebellar specimens were collected just after sacrification. Sagittal cerebellar slices for light microscopic examination were fixed in $10 \%$ neutral formol saline, dehydrated, embedded in paraffin wax, cut into $5 \mu \mathrm{m}$ sections They were stained with hematoxylin and eosin and cresyl fast violet [35].

\section{Immunohistochemical study}

Immunohistochemical detection of GFAP, $\operatorname{Er} \beta$, and Bax protein was carried out using streptavidin-biotin complex immunoperoxidase system. Serial sections of paraffin-embedded specimens were deparaffinized on charged slides. The sections were incubated in $0.1 \%$ hydrogen peroxide for $30 \mathrm{~min}$ to block the endogenous peroxidase and then incubated with the primary antibody.

\section{Regarding detection of GFAP}

Sections were incubated with mouse anti-GFAP antibody (Cat. No. MS- 280- R7, Lab Vision Corporation, Fremont, USA) diluted in 1:100 in Lab Vision antibody diluent (Cat. TA- 125- UD). The primary antibody was incubated for $20 \mathrm{~min}$ at room temperature. After several washes with phosphate buffer solution (PBS), primary antibodies were detected by incubation with biotinylated goat anti-mouse IgG (Zymed Laboratories; South San Francisco, CA, USA) for $30 \mathrm{~min}$ at room temperature [36].

\section{Regarding ER $\beta$ expression}

The sections were incubated rabbit polyclonal IgG anti-rat $\operatorname{Er} \beta$ antibody (Cat. No. PA1-311, Thermo Fisher Scientific, Rockford, USA) at $1-2 \mu \mathrm{g} / \mathrm{mL}$ diluted in PBS for $30 \mathrm{~min}$ at room temperature. After several washes with PBS, primary antibodies were detected by incubation with biotinylated anti-rabbit antibodies (versal kits, Zymed laboratories) for $30 \mathrm{~min}$ at room temperature [36]. 
Citation: Ahmed SM, Abdelrahman SA, Shalaby SM (2017) Therapeutic Potential of Mesenchymal Stem Cells vs. Estradiol Benzoate or Avosoya on the Cerebellar Cortex of Ovariectomized Adult Albino Rats. J Cytol Histol 8: 444. doi: 10.4172/2157-7099.1000444

\section{Regarding Bax protein expression}

Sections were incubated with Bax mouse monoclonal anti-rat antibody (CAT. MAS- 14003, Lab Vision Corporation, Fremont, USA) dilution 1:200 in PBS for $30 \mathrm{~min}$ at room temperature. After several washes with PBS, primary antibodies were detected by incubation with biotinylated goat anti-mouse IgG (Zymed Laboratories; South San Francisco, CA, USA) for 30 min at room temperature [36].

Thereafter, all sections were incubated with the streptavidin-biotin peroxidase complex for $30 \mathrm{~min}$ at room temperature. After washing with PBS, reactions were visualized with 3', 3Regular-diaminobenzidinetetrahydrochloride (DAB - Sigma-Aldrich Chemical Co., St. Louis, USA) used as chromogen to visualize antibody binding. The sections were counterstained with Mayer's hematoxylin, dehydrated and mounted. For negative control sections, the primary antibody was replaced with PBS [36].

\section{Anti-oxidant measurements in cerebellum homogenate}

For preparation of the cerebellar homogenate, the cerebellar tissue was homogenized with $5 \mathrm{~mL}$ of cold buffer $(50 \mathrm{mmol} / \mathrm{L}$ potassium phosphate, $\mathrm{pH} 7.4,1 \mathrm{mmol} / \mathrm{L}$ EDTA) per gram of tissue. The homogenate was centrifuged at $4000 \mathrm{RPM}$ for $15 \mathrm{~min}$ at $4^{\circ} \mathrm{C}$, and the supernatant was stored on ice. If not assayed on the same day, the samples were frozen at $-80^{\circ} \mathrm{C}$. The superoxide dismutase (SOD) activity (in U/g tissue) was determined according to Nishikimi et al. [37]. Catalase (CAT) activity (in U/g tissue) was assessed by means of the method of Aebi [38]. Reduced glutathione (GSH) was determined according to the method of Beutler et al. [39] (All the above-mentioned kits were purchased from Biodiagnostic).

\section{Histo-morphometric analysis}

The image analyzer computer system Leica Qwin 500 (Leica Ltd, Cambridge, UK) at the Image Analyzing Unit of Pathology Department, Faculty of Dentistry, Cairo University, Egypt, was used to evaluate Purkinje cell quantitation, the area percent of GFAP, $\operatorname{Er} \beta$ and Bax protein.

Using the interactive measure menu, the number of Purkinje cells was counted in ten fields in each specimen and the mean value was obtained for each group. The count was performed using an objective lens of magnification $\times 10$.

The area percent was measured using the interactive measure menu. The measuring frame of a standard area equal to $118476.6 \mathrm{~mm}^{2}$ was chosen so that the brown positive immune reaction could be seen and masked by blue binary colour to be measured. Ten readings from five non-overlapping sections from each rat of all groups were examined.

\section{Statistical analysis}

All data were expressed as mean \pm SD. Statistical analysis was performed using the Statistical Package for the Social Sciences (SPSS) software, version 13.00 (Chicago, Illinois, USA). Statistical significance was determined by one-way analysis of variance for differences between the means of different groups. Further analysis was carried out using the post-hoc test to compare the parameters between the different groups with each other. Probability of P less than 0.05 was considered statistically significant.

\section{Results}

\section{Characterization of HUCB-MSCs}

Real time PCR analysis demonstrated a positive expression for $\mathrm{CD}_{105}$ in HUCB-MSCs, but was negative for $\mathrm{CD}_{34}$.

\section{Detection of HUCB-MSCs homing in rat cerebellum}

Sections of the cerebellar cortex of HUCB-derived MSCs treated group showed PKH26 labelled stem cells appearing as bright dots (Figure 1a). Agarose gel electrophoresis of PCR product (329 bp) of the human albumin gene showed positive results in the rats receiving HUCB-MSCs (lanes 3-7) and negative results for rats not received HUCB-MSCs (lanes 1, 2) (Figure 1b).

\section{Histological results}

Light microscopic examination of the control subgroups showed no detectable differences, so, subgroup la was considered as the control group.

H\&E stained sections of the control cerebellar cortex revealed three distinctive layers; molecular, Purkinje cell and granular layers. Molecular layer was formed of few small stellate cells located superficially and basket cells were found deeper near the Purkinje cell layer. Purkinje cells were arranged as a single row along the outer margin of the granular layer. It was composed of large pyriform somata of Purkinje neurons with vesicular nuclei, and basophilic cytoplasm. Granular layer was composed of tightly packed small rounded cells with deeply stained nuclei. Clear spaces (cerebellar islands or glomeruli) were interspersed among these cells (Figure 2a). Group II cerebellar cortex showed decreased density of neurons in the three cortical layers. Molecular layer appeared with small dark nuclei, Purkinje cells were distorted with pyknotic nuclei. Granule cells appeared less crowded than in the control group (Figure 2b), in other sections of the same group, marked vacuolations were observed in the three layers of cerebellar cortex. Reduction in the number of Purkinje cells was observed with irregular outlines, dark stained cytoplasm and hardly identified nuclei. Prominent perineuronal spaces were detected in the molecular layer around basket and stellate cells (Figure $2 b^{*}$ ). Group III cerebellar cortex showed a slight increase in the neuronal density in the three cortical layers as compared to control group. Most Purkinje cells had vesicular nuclei, but others still had pyknotic nuclei (Figure 2c). In Group IV cerebellar cortex, normal neuronal cells in the molecular layer, Purkinje cell layer and granular layer were detected (Figure 2d). Group V cerebellar cortical cells appeared normal. Stellate and basket cells in the molecular layer were detected. Purkinje cells were pyriform in shape with vesicular nuclei, and basophilic cytoplasm. Small rounded cells with deeply stained nuclei appeared in the granular layer (Figure 2e).

Examination of cresyl fast violet stained sections in the cerebellar

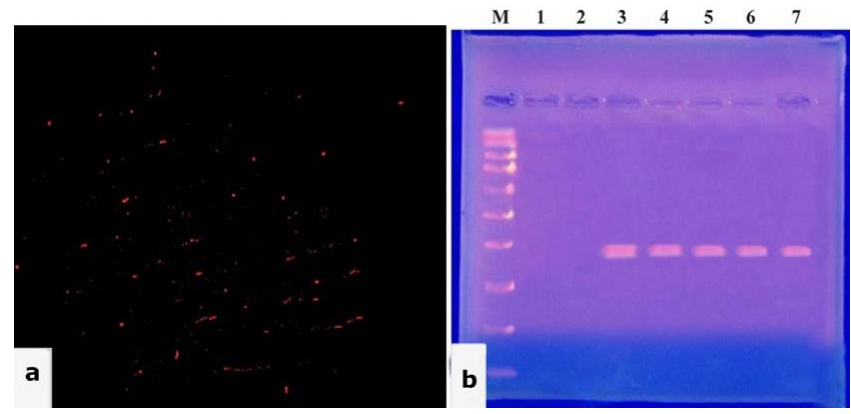

Figure 1: (a) HUCB-MSCs treated cerebellar cortex showing PKH26 labeled cells appear as bright dots (arrows); (b) Agarose gel electrophoresis of PCR product $(329 \mathrm{bp}$ ) of human albumin gene showing positive results in rats receiving HUCBMSCs (lanes 3-7) and negative results for rats not received HUCBMSCs (lanes 1, 2) (Fluorescent Microscope X 200). 


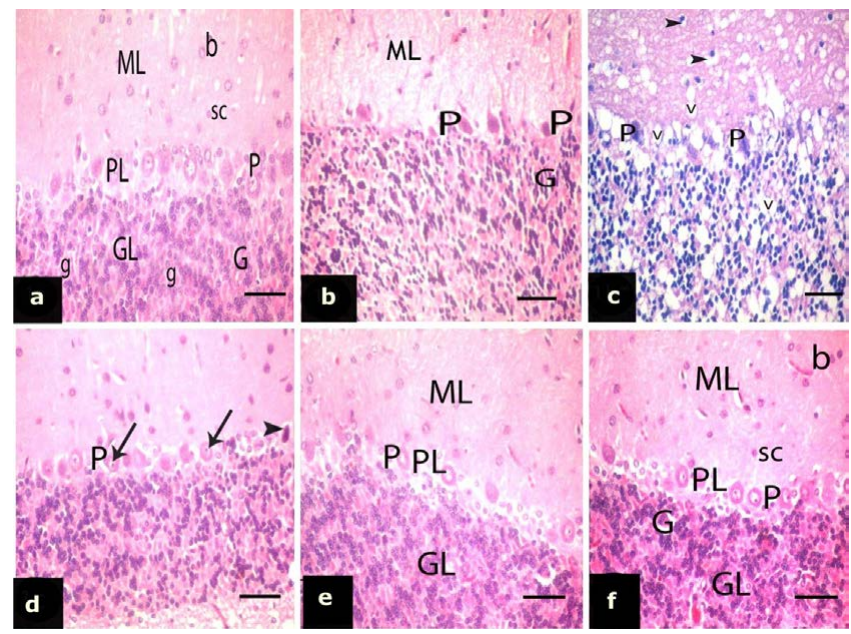

Figure 2: (a) H\&E stained sections of the control cerebellar cortex showing the molecular layer (ML), Purkinje cell layer $(\mathrm{PL})$ and granular layer $(\mathrm{GL})$. Small scattered stellate (sc) and basket cells (b) in the molecular layer. Purkinje cells $(P)$ are pyriform with vesicular nuclei, prominent nucleoli and basophilic cytoplasm. Tightly packed small rounded cells $(G)$ with deeply stained nuclei, among these cells cerebellar islands or glomerulus $(\mathrm{g})$ appear in the granular layer; (b) Group II cerebellar cortex showing decreased density of neurons in the three cortical layers. Molecular layer (ML) appears with small dark nuclei, Purkinje cells $(P)$ are distorted with pyknotic nuclei. Granule cells $(G)$ appear less crowded and have dark nuclei than in the control group; $\left(b^{*}\right)$ In other sections of GIl marked vacuolations (v) are observed in the three layers. Reduction in the number of Purkinje cells $(P)$. Purkinje cells have irregular outlines, dark stained cytoplasm and hardly identified nuclei. Prominent perineuronal spaces (arrow heads) are observed in the molecular layer around basket and stellate cells; (c) Group III cerebellar cortex showing preservation of the normal architecture, slight increase in the neuronal density in the three cortical layers. Most Purkinje cells $(P)$ have vesicular nuclei (arrow) but still others have pyknotic nuclei (arrow head); (d) A section in Group IV cerebellar cortex showing neuronal cells in the molecular layer (ML), Purkinje cell layer $(\mathrm{PL})$ and granular layer (GL) are normal; (e) In Group V cerebellar cortical cells appear normal, stellate (sc) and basket cells (b) in the molecular layer (ML), Purkinje cells $(\mathrm{P})$ are pyriform with vesicular nuclei, prominent nucleoli and basophilic cytoplasm and small rounded cells $(G)$ with deeply stained nuclei appear in the granular layer (GL) (H\&E×400, scale bar $30 \mu \mathrm{m})$.

cortex of the control group showed purple Nissl granules in the perikarya of Purkinje cells that appeared as a ring around their nuclei (Figure 3a). Sections in the cerebellar cortex of Group II showed illdefined purple Nissl granules in the perikarya of Purkinje cells (Figure 3b). Sections of cerebellar cortex of Groups III, IV and V stained with cresyl fast violet showed purple Nissl granules in the perikarya of Purkinje cells (Figures 3c-3e).

\section{Immuno-histochemical results}

Immunohistochemical reaction for identification of GFAP in the control group revealed positive reaction in the cytoplasm and processes of astrocytes in the cerebellar cortex (Figure 4a). Group II cerebellar cortex showed increase in the intensity and number of positive reaction in the cytoplasm and processes of astrocytes as compared to the control group (Figure 4b). Immuno-peroxidase reaction of GFAP in Groups III, and IV revealed positive immunoreaction in the cytoplasm and processes of astrocytes in the cerebellar cortex (Figures $4 \mathrm{c}$ and $4 \mathrm{~d}$ ). Positive immunoreaction in the cytoplasm and processes of some astrocytes in the cerebellar cortex was detected in Group V (Figure 4e).

Regarding $\operatorname{Er} \beta$ immunoreaction, GI cerebellar cortex revealed strong positive reaction in the cytoplasm of Purkinje cells (Figure 5a) that turned faint positive in the cytoplasm of Group II Purkinje cells

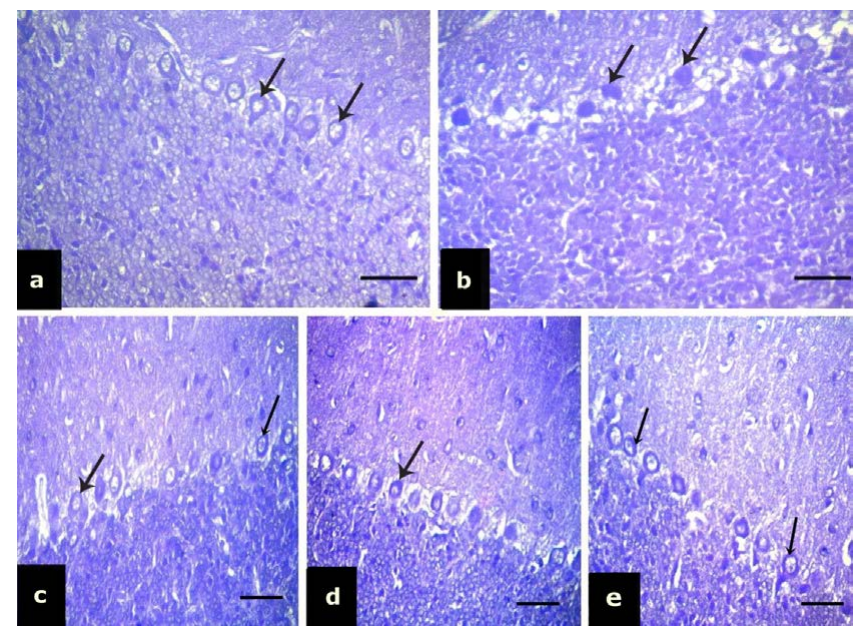

Figure 3: (a) A photomicrograph of a section in the control cerebellar cortex stained with cresyl fast violet showing purple Nissl granules (arrows) in the perikarya of Purkinje cells that appeared as a ring around their nuclei; (b) A photomicrograph of a section in the cerebellar cortex of Group II showed illdefined purple Nissl granules (arrows) in the perikarya of Purkinje cells; (c, $\mathrm{d}$ and e) photomicrographs of sections in of the cerebellar cortex of Group III, Group IV and Group V stained with cresyl fast violet showing purple Niss granules in the perikarya of Purkinje cells as compared to the control group (arrows) (Cresyl fast violet x 400, scale bar $30 \mu \mathrm{m}$ ).

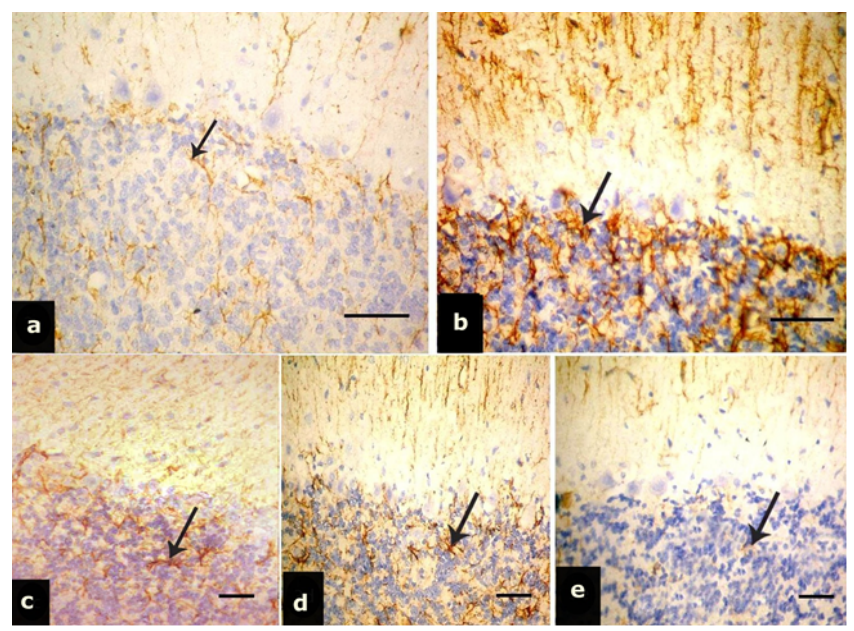

Figure 4: (a) Immunoperoxidase reaction for GFAP in the control group reveals positive immunoreaction in the cytoplasm and processes of astrocytes in the cerebellar cortex (arrows); (b) Immunoperoxidase reaction for demonstration GFAP in Group II cerebellar cortex showing increase in intensity and number of positive reaction in the cytoplasm and processes of astrocytes as compared to the control group (arrows); (c, d and e) Immunoperoxidase reaction for GFAP in Groups III, IV and GV respectively reveals positive immunoreaction in the cytoplasm and processes of astrocytes in the cerebellar cortex (arrows) (Immunoperoxidase reaction of GFAP x 400, scale bar $30 \mu \mathrm{m}$ ).

(Figure 5b). In Group III cerebellar cortex, strong positive reaction was noticed in the cytoplasm of some Purkinje cells, however, Group IV and Group V revealed strong positive immunoreaction in the cytoplasm of almost all Purkinje cells (Figures 5c-5e).

Immunoperoxidase reaction of Bax in the control cerebellar cortex revealed negative reaction in the cytoplasm of Purkinje cells (Figure 6a) that became strong positive in Purkinje cells and basket cells of Group II (Figure 6b). Decreased expression of Bax immunoreaction that was 
Citation: Ahmed SM, Abdelrahman SA, Shalaby SM (2017) Therapeutic Potential of Mesenchymal Stem Cells vs. Estradiol Benzoate or Avosoya on the Cerebellar Cortex of Ovariectomized Adult Albino Rats. J Cytol Histol 8: 444. doi: 10.4172/2157-7099.1000444

observed as faint positive in the cytoplasm of Group III and Group IV Purkinje cells (Figures $6 \mathrm{c}$ and $6 \mathrm{~d}$ ). In Group V, negative reaction in the cytoplasm of Purkinje cells was detected (Figure 6e).

\section{Histomorphometric and statistical results}

Statistically significant decrease in the mean number of Purkinje cells was detected in Group II as compared to Group I, Group III, Group IV and Group V. No statistically significant difference was noticed between Group I as compared to Groups III, IV and V (Table 1).

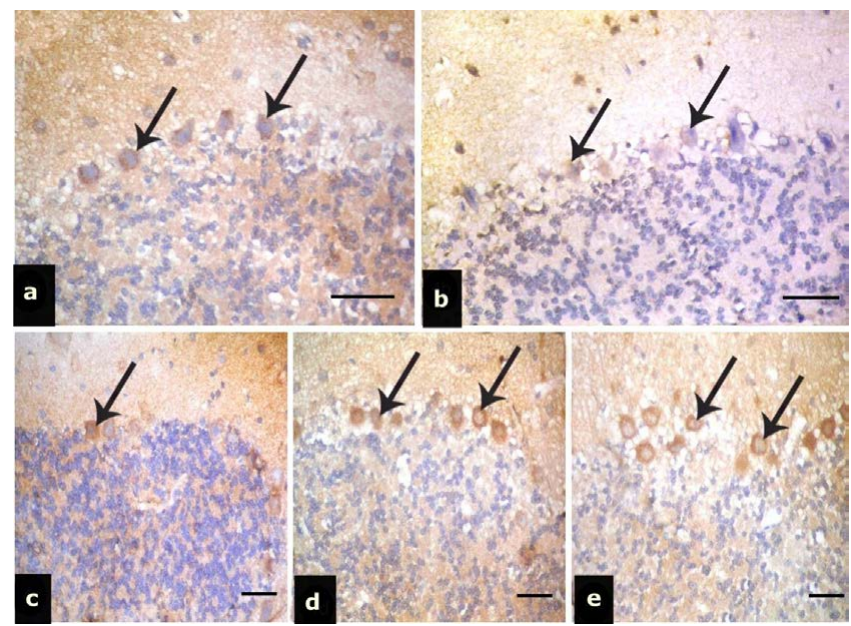

Figure 5: (a) Immunoperoxidase reaction for $\operatorname{Er} \beta$ in the control cerebellar cortex reveals strong positive immunoreaction in the cytoplasm of Purkinje cells (arrows); (b) Immunoperoxidase reaction for $\operatorname{Er} \beta$ in Group II cerebellar cortex reveals faint positive immunoreaction in the cytoplasm of Purkinje cells (arrows); (c) Immunoperoxidase reaction for $\operatorname{Er} \beta$ in Group III reveals strong positive immunoreaction in the cytoplasm of some Purkinje cells (arrows); (d, e) Immunoperoxidase reaction for $\operatorname{Er} \beta$ in Group IV and Group V respectively reveals strong positive immunoreaction in the cytoplasm of almost all Purkinje cells (arrows) (Immunoperoxidase reaction of Erß $\times$ 400, scale bar $30 \mu \mathrm{m}$ ).

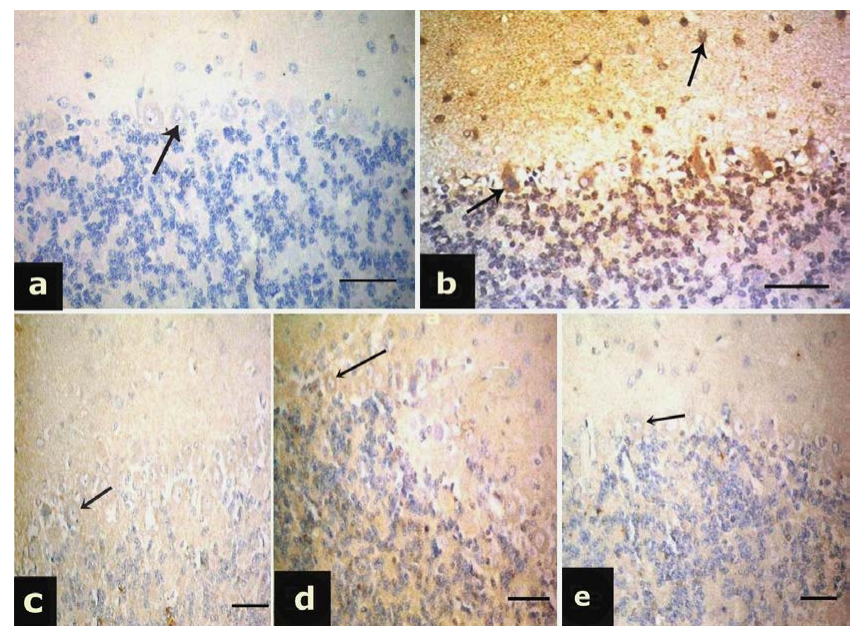

Figure 6: (a) Immunoperoxidase reaction of Bax protein in the control cerebellar cortex reveals negative reaction in the cytoplasm of Purkinje cells (arrow); (b) Immunoperoxidase reaction of Bax protein for Group II cerebellar cortex reveals strong positive reaction in the cytoplasm of Purkinje cells and Basket cells (arrows); (c, d) Immunoperoxidase reaction of Bax protein in Groups III, and IV reveals faint positive reaction of Bax protein in the cytoplasm of Purkinje cells (arrows); (e) Immunoperoxidase reaction of Bax protein in Group V reveals negative reaction in the cytoplasm of Purkinje cells (arrow) (Immunoperoxidase reaction of Bax protein x 400, scale bar $30 \mu \mathrm{m}$ ).
Statistically significant increase in the mean area percent of GFAP immunoreaction was noticed in GII as compared to Group I, Group III, Group IV and Group V. No statistically significant difference was seen between Group I as compared to Groups III, IV and V (Table 2).

Statistically significant decrease in the mean area percent of $\operatorname{Er} \beta$ immunoreaction was noticed in Group II as compared to Group I, Group III, Group IV and Group V. No statistically significant difference was detected between Group I as compared to Groups III, IV and V (Table 3).

Statistically significant increase in the mean area percent of Bax immunoreaction was detected in Group II as compared to Groups I, III, IV and V. No statistically significant difference was detected between Group III, IV and V as compared to Group I (Table 4).

\section{Anti-oxidative parameters results}

Statistically significant decrease $(\mathrm{P}<0.05)$ in the levels of SOD, CAT and GSH enzymes was detected in Group II cerebellar tissue when compared to Group I values. No statistically significant difference was

\begin{tabular}{|c|c|c|c|c|}
\hline & \multicolumn{2}{|c|}{ Mean \pm SD } & $\mathbf{F}$ & P-value \\
\hline Group I & \multicolumn{2}{|c|}{$26.304 \pm 0.71$} & \multirow[t]{4}{*}{1461.33} & \multirow[t]{4}{*}{$<0.01^{*}$} \\
\hline Group II & \multicolumn{2}{|c|}{$9.360 \pm 0.24$} & & \\
\hline Group III & \multicolumn{2}{|c|}{$20.190 \pm 0.05$} & & \\
\hline Group IV & \multicolumn{2}{|c|}{$23.101 \pm 0.12$} & & \\
\hline Group V & \multicolumn{2}{|c|}{$25.981 \pm 0.74$} & & \\
\hline \multicolumn{5}{|c|}{ LSD for comparison between groups } \\
\hline & Group I & Group II & Group III & Group IV \\
\hline Group II & $<0.01^{*}$ & & $<0.01^{*}$ & $<0.01^{*}$ \\
\hline Group III & 0.111 & $<0.01^{*}$ & & 0.611 \\
\hline Group IV & 0.523 & $<0.01^{*}$ & 0.611 & \\
\hline Group V & 0.107 & $<0.01^{*}$ & 0.123 & 0.317 \\
\hline
\end{tabular}

Table 1: The mean number of Purkinje cells in different studied groups.

\begin{tabular}{|c|c|c|c|c|}
\hline & \multicolumn{2}{|c|}{ Mean \pm SD } & $\mathbf{F}$ & P-value \\
\hline Group I & \multicolumn{2}{|c|}{$36.1 \pm 5.43$} & \multirow[t]{4}{*}{18.3} & \multirow[t]{4}{*}{$<0.01^{*}$} \\
\hline Group II & \multicolumn{2}{|c|}{$80.06 \pm 10.71$} & & \\
\hline Group III & \multicolumn{2}{|c|}{$40.23 \pm 15.25$} & & \\
\hline Group IV & \multicolumn{2}{|c|}{$39.8 \pm 7.127$} & & \\
\hline Group V & \multicolumn{2}{|c|}{$36.9 \pm 6.94$} & & \\
\hline \multicolumn{5}{|c|}{ LSD for comparison between groups } \\
\hline & Group I & Group II & Group III & Group IV \\
\hline Group II & $<0.01^{*}$ & & $<0.01^{*}$ & $0.034^{*}$ \\
\hline Group III & 0.325 & $<0.01^{*}$ & & 0.148 \\
\hline Group IV & 0.26 & $0.034^{*}$ & 0.148 & \\
\hline Group V & 0.174 & $<0.01^{*}$ & 0.362 & 0.133 \\
\hline
\end{tabular}

Table 2: Area percent of GFAP immunoreaction in different studied groups.

\begin{tabular}{|c|c|c|c|c|}
\hline & \multicolumn{2}{|l|}{ Mean \pm SD } & $\mathbf{F}$ & P-value \\
\hline Group I & \multicolumn{2}{|l|}{$67 \pm 0.43$} & \multirow[t]{4}{*}{44.72} & \multirow[t]{4}{*}{$<0.01^{*}$} \\
\hline Group II & \multicolumn{2}{|l|}{$20 \pm 0.04$} & & \\
\hline Group III & \multicolumn{2}{|l|}{$53.6 \pm 2.1$} & & \\
\hline Group IV & \multicolumn{2}{|l|}{$60 \pm 0.23$} & & \\
\hline Group V & \multicolumn{2}{|l|}{$64 \pm 0.88$} & & \\
\hline \multicolumn{5}{|c|}{ LSD for comparison between groups } \\
\hline & Group I & Group II & Group III & Group IV \\
\hline Group II & $<0.021^{*}$ & & $<0.01^{*}$ & $<0.017^{*}$ \\
\hline Group III & 0.325 & $<0.01^{*}$ & & 0.513 \\
\hline Group IV & 0.152 & $<0.017^{*}$ & 0.513 & \\
\hline Group V & 0.417 & $<0.01^{*}$ & 0.215 & 0.215 \\
\hline
\end{tabular}

Table 3: Area percent of $\operatorname{Er} \beta$ immunoreaction in different studied groups. 
observed between Groups III, IV or V when compared to Group I (Table 5).

\section{Discussion}

In the present study, H\&E stained sections of Group II cerebellar cortex showed a decrease in the neuronal density and vacuolations in the three cortical layers with ssignificant Purkinje cell loss. These findings can be attributed to accumulation of damaged molecules (proteins, nucleic acids, lipids) resulting from apoptosis and oxidative stress mechanisms [40]. Chung et al. [41] stated that Purkinje cells were the sites of functionally significant oxidative damage in aged rats. Decreased number of granule cells in the same group might also be related to oxidative and metabolic stress associated with ovariectomy. In addition, granule cells have a developmental dependency on their synaptic target; Purkinje cells. So, loss of Purkinje cells may result in subsequent granule cell death [42]. The current findings provided a plausible mechanism underlying the clinical observation of increased risk of Alzheimer's disease in women who had undergone oophorectomy prior to menopause $[43,44]$.

Group III cerebellar cortex showed an increase in the number of Purkinje and granule cells as compared to Group II that was proved statistically. It can be explained by the effect of estradiol on neuronal cells [7]. They stated that, estradiol induce the expression of some neurotrophic factors as brain derived neurotrophic factor (BDNF) which is a member of the neurotrophin gene family. It plays a crucial role in survival, differentiation and phenotypic maintenance of various neuronal populations within the normal and diseased brain. In another study, administration of estrogen to newborn mice, increased the level of BDNF in the cerebellum. BDNF promoted Purkinje dendritic growth, spinogenesis and synaptogenesis. Estrogen was found to increase presynaptic and postsynaptic proteins, such as syntaxin, synaptophysin and spinophilin in the CA1 region of the primate hippocampus $[45,46]$. Although OVX was found to induce a decrease in brain glucose consumption in a rodent model, estrogen therapy (ET) users vs. nonusers exhibited a significant difference in regional cerebral blood flow relative to activation patterns during memory tasks $[47,48]$. It can also regulate the expression of anti-apoptotic genes, such as increasing Bcl-2 expression [25]. A major problem facing research

\begin{tabular}{|c|c|c|c|c|}
\hline & \multicolumn{2}{|l|}{ Mean \pm SD } & $\mathbf{F}$ & P-value \\
\hline Group I & \multicolumn{2}{|l|}{$0.24 \pm 0.03$} & \multirow[t]{4}{*}{135.6} & \multirow[t]{4}{*}{$<0.01^{*}$} \\
\hline Group II & \multicolumn{2}{|l|}{$0.86 \pm 0.07$} & & \\
\hline Group III & \multicolumn{2}{|l|}{$0.30 \pm 0.01$} & & \\
\hline Group IV & \multicolumn{2}{|l|}{$0.23 \pm 0.02$} & & \\
\hline Group V & \multicolumn{2}{|l|}{$0.22 \pm 0.04$} & & \\
\hline \multicolumn{5}{|c|}{ LSD for comparison between groups } \\
\hline & Group I & Group II & Group III & Group IV \\
\hline Group II & $<0.01^{*}$ & & $<0.01^{*}$ & $<0.01^{*}$ \\
\hline Group II & 0.235 & $<0.01^{*}$ & & 0.32 \\
\hline Group IV & 0.411 & $<0.01^{*}$ & 0.32 & \\
\hline Group V & 0.126 & $<0.01^{*}$ & 0.175 & 0.241 \\
\hline
\end{tabular}

Table 4: Area percent of Bax immunoreaction in different studied groups.

\begin{tabular}{|c|c|c|c|c|}
\hline Groups & & SOD & GSH & CAT \\
\hline Group I & \multirow{4}{*}{ Mean \pm SD } & $30.5 \pm 0.12$ & $10.3 \pm 0.13$ & $37.7 \pm 0.71$ \\
\hline Group II & $16.4 \pm 0.32$ & $5.4 \pm 0.52$ & $25.5 \pm 0.43$ \\
\hline Group III & $27 \pm 0.01$ & $8.6 \pm 0.32$ & $34.1 \pm 0.14$ \\
\hline Group IV & & $28.5 \pm 0.27$ & $9.0 \pm 0.21$ & $35.2 \pm 0.90$ \\
\hline Group V & & $29.3 \pm 0.04$ & $9.1 \pm 0.12$ & $36.7 \pm 0.62$ \\
\hline
\end{tabular}

Table 5: Levels of antioxidant enzymes in different studied groups. of the protective effects of estrogens on biological systems is its serious side effects and feminizing effects so, it cannot be administered to men [49].

In the current work, H\&E stained sections of Group IV cerebellar cortex showed preservation of the normal cerebellar cortex architecture. This may be explained by the effect of phytoestrogens present in Avosoya. Phytoestrogens were significantly increase the expression of genes of various proteins related to synaptic formation in the hippocampus. Increased expression of such genes may be partially responsible for the improved learning and memory performance following dietary supplementation of estradiol or phytestrogens in ovariectomized rats [50]. Genistein which is the major phytoestrogen present in soy prevents both mitochondrial peroxide production and cytochrome $c$ liberation. Therefore, phytoestrogens mimic the estrogens action but they do not have their side effects. Moreover, phytoestrogens have the advantage of treating both men and women and they do not show any significant feminizing effects. Limited effects on cardiovascular system or on the promotion of cancer have been reported [51].

Group V showed normal neuronal cells in the molecular layer, Purkinje cell layer and granular layer. Cendelin [52] reported that various types of stem cells can be used for experimental neurotransplantation such as: embryonic or adult neural stem cells, embryonic stem cells, adult stem cells, mesenchymal stem cells isolated from various tissues. In a study of Chen et al. [53], HUCBMCs were found to express BDNF and other factors such as NT-3 and GDNF. These three neurotropic factors are implicated in Purkinje cell survival and differentiation. Jones et al. [54] injected mouse MSC in the cerebellum of newborn Lurcher mutant mice (an animal model for cerebellar ataxia with postnatal death of Purkinje cells). They found that, the transplanted cells migrated and could improve the locomotor function probably providing trophic and neuroprotective effects for Purkinje cells. Although multiple injections with MSCs is not really a practical solution with menopausal women, however, it could be applied in severe cases and would be more effective than long-term administration of estradiol or phytoestrogens.

In the present work, ill-defined purple Nissl granules were found in the perikarya of Purkinje cells in cresyl fast violet stained sections of Group II. This could be explained by decreased rate of protein synthesis in ovariectomized rat cerebella [55]. Nissl granules were detected in the perikarya of Purkinje cells in Groups III, IV and V. This showed improvement in the function of these neurons due to oxidative stress suppression, attenuating OVX-enhanced tendency towards neurodegeneration and increased production of ribosomal subunits [42].

Immunoperoxidase reaction of GFAP in Group II showed increased intensity and number of positive reaction in the cytoplasm and processes of astrocytes as compared to the control group. Groups III and IV revealed positive immunoreaction in the cytoplasm and processes of astrocytes. Positive immunoreaction in the cytoplasm and processes of some astrocytes in the cerebellar cortex was detected in Group V. This was proved statistically by significant increase in area percent of GFAP immunoreaction in Group II as compared to other groups. Oxidative stress was claimed as the molecular mechanism of astrocyte activation which is a consequence of increasing need for neuronal protection [56]. Sofroniew and Vinters [57] reported that any mechanical, chemical or degenerative insults to the brain, stimulates astrocyte proliferation and hypertrophy with increased synthesis of GFAP leading to astrogliosis. MSCs were found to prevent the overexpression of GFAP in cerebellum. This reduced GFAP protein 
levels and immune reactivity in the cerebellum suggests that grafted cells could be involved in the modulation of astrogliosis [31].

Purkinje cells were the major sites for neurosteroids formation including estradiol in rats and other vertebrates. Estradiol was found to promote dendritic growth of Purkinje cells in newborn rats [5860]. Consequently, estradiol may act directly on the Purkinje cells through $\operatorname{Er} \beta$-mediated mechanism to stimulate dendritic growth, spinogenesis and synaptogenesis. Significant decrease in the area percent of $\operatorname{Er} \beta$ immunoreaction in Group II of the present study was detected as compared to the other groups. A possible explanation is that, the expression of $\operatorname{Er} \beta$ is dependent on the continuous intra and extracellular presence of estrogen. Estrogen was found to regulate the transcription of $\operatorname{Er} \beta$ intracellularly. So, estrogen could affect its own receptor concentrations through increasing target tissue responsiveness to itself [61]. On the other hand, decreased density of granule cells associated with decreased number of Purkinje cells in Group II of the present work represent another explanation as both cells express $\operatorname{Er} \beta$ [42]. Isoflavones act as agonists of Ers. Isoflavones and estradiol are competing for their binding on Ers. In a state with low levels of endogenous estrogens (men, women in menopause and after OVX), the estrogenic activity of isoflavones may be manifested [62].

Immuno histo-chemical reaction of Bax protein in Group II showed strong cytoplasmic positive reaction in Purkinje cells as compared to the control group that decreased in Group's III, IV. In Group V, negative reaction in the cytoplasm of Purkinje cells was detected. This was proved statistically; significant increase in area percent of Bax immunoreaction in Group II as compared to other groups. Bcl-2 and Bax are characteristic anti-apoptotic and proapoptotic genes, respectively. Apoptosis was reported in OVX rats' hippocampus with an obvious decline in Bcl-2 and an increase in Bax [26]. Borrás et al. [49] explained apoptosis of neuronal cells in OVX by the involvement of mitochondria via the intracellular pathway. This pathway includes, the release of cytochrome $\mathrm{c}$ from the organelle resulting in more cytochrome $\mathrm{c}$ in the cytosol leading to the activation of caspases. The anti-apoptotic effect of estrogen is biologically relevant to many processes. One of the most important is its effect on the expression of apoptosis-related genes [63]. Estrogen was found to affect the expression of $\mathrm{Bcl}-2$ through the regulation of estrogen receptors, particularly $\operatorname{Er} \beta$, resulting in inhibition of apoptosis [64]. Genistein (the major phytoestrogen present in soy), prevents both mitochondrial peroxide production and cytochrome $\mathrm{c}$ liberation. Therefore, phytoestrogens mimic the action of estrogen, but they do not have their side effects [51]. This protective effect may come from the stimulation of $\operatorname{Er} \beta$, which activates the estrogen response element of the Bcl-2 gene, and then increases transcription and translation to up regulate the expression of Bcl-2 [35]. Dasari et al. [65] found that intravenous administration of HUCB-MSCs modulates the expression of proteins involved in cell survival. Also, HUCB-MSCs were found to up regulate $\mathrm{Bcl}-2$ protein expression in the cerebellum of ataxic rats, which enhanced the survival of different types of neurons, including those of the granular layer. Additionally, Bcl-2 may contribute to the maintenance of the injected stem cells in the cerebellum of ataxic rats $[66,67]$.

HUCB-MSCs in Group V were able to reach the cerebellum of ovariectomized rats after intravenous administration. It was evidenced by PCR detection of the human albumin gene in rats receiving HUCBMSCs. These findings were in accordance with Aleynik et al. [68] who reported stem cell homing to the brain. So, they can be the future form of treatment to bypass the blood brain barrier. Calatrava-Ferreras et al. [31] reported HUCBMCs reached the cerebellum and brain stem of rats. They added that, grafted cells reduced neuronal loss, prevented cerebellar glial reactivity and hence, improved motor coordination in ataxic rats.

Decreased activity of antioxidant enzymes SOD, GSH and CAT in the cerebellum of ovariectomized rats in the present study compared to control group explains apoptosis found in the sections according to $\mathrm{Al}$ Bazi [24]. OVX was demonstrated to increase oxidative stress markers in human Alzheimer diseased patients, whereas estrogen treatment initiated at time of OVX prevented the OVX-induced oxidative damage [69]. Estradiol was postulated to be antioxidant because of the phenolic structure of the A ring of the steroid molecule [70]. Estradiol when administered to a patient is given in a dose of 50 micrograms per day, while vitamin $\mathrm{E}$ is usually given in a dose of approximately 500 mg per day. Thus, estradiol should be 10,000 times more potent than vitamin $\mathrm{E}$ as an antioxidant [71]. It was also found to exert protective effects against oxidative stress by inhibiting lipid peroxidation and subsequently preserving $\mathrm{Ca}^{2}$ homeostasis, mitochondrial membrane potential and ATP levels [24]. Phytoestrogens, after binding to estrogen receptors (Ers), activate a number of signaling pathways which lead to the phosphorylation and thus activation of NFkB. On entering the nucleus, NFKB activates transcription of a number of longevityassociated genes such as GSH or SOD [51]. HUCBMSCs normalized the antioxidant variables that were downregulated by the disease as, SOD, GSH and CAT. The relation of MSCs and the oxidative-antioxidative status was reported $[21,72]$.

\section{Conclusion}

Estrogen deprivation showed obvious changes in the histological structure of rat cerebellar cortex, such changes improved after estradiol supplementation; however, estradiol is known to produce serious side effects. So, searching for alternative therapy, as the natural phytoestrogens found in Avosoya or the recent application of MSCs may provide the hope for treatment of neurodegenerative disorders in postmenopausal women. They may play an important role in the future treatment of many neurodegenerative diseases including ataxias, to avoid the side effects of hormone replacement therapy.

\section{References}

1. Wolf U, Rapoport M, Schweizer T (2009) Evaluating the affective component of the cerebellar cognitive affective syndrome. The Journal of Neuropsychiatry and Clinical Neurosciences 21: 245-253.

2. Fine $E$, lonita $C$, Lohr $L$ (2002) The history of the development of the cerebellar examination. In Seminars in Neurology 22: 375-384.

3. Hedges V, Ebner T, Meisel R, Mermelstein P (2012) The cerebellum as a target for estrogen action. Frontiers in Neuroendocrinology 33: 403-411.

4. Ikeda Y, Nagai A (2006) Differential expression of the estrogen receptors alpha and beta during postnatal development of the rat cerebellum. Brain Research 1083: $39-49$.

5. Belcher S (1999) Regulated expression of estrogen receptor alpha and beta mRNA in granule cells during development of the rat cerebellum. Developmental Brain Research 115: 57-69.

6. Snyder M, Smejkalova T, Forlano P, Woolley C (2010) Comparison of Piascledine (Avocado and Soybean Oil) and Hormone Replacement Therapy in Menopausal-Induced Hot Flashing. Iranian Journal of Pharmaceutical Research 10: 941-951.

7. Pan M, Li Z, Yeung V, Xu R (2010) Dietary supplementation of soy germ phytoestrogens or estradiol improves spatial memory performance and increases gene expression of BDNF, TrkB receptor and synaptic factors in ovariectomized rats. Nutrition \& Metabolism 7: 1-7.

8. Panahia Y, Beiraghdar F, Kashanic N, Baharie N, Dadjo Y (2011) Multiple ER 
Citation: Ahmed SM, Abdelrahman SA, Shalaby SM (2017) Therapeutic Potential of Mesenchymal Stem Cells vs. Estradiol Benzoate or Avosoya on the Cerebellar Cortex of Ovariectomized Adult Albino Rats. J Cytol Histol 8: 444. doi: 10.4172/2157-7099.1000444

beta antisera label in ER beta knockout and null mouse tissues. Journal of Neuroscience Methods 188: 226-234.

9. Pilsakova L, Riecansky I, Jagla F (2010) The Physiological Actions of Isoflavone Phytoestrogens. Physiological Research 59: 651-664.

10. Kiasalari Z, Khalili M (2008) Comparison between the Effects of Estrogen and Soy Extract on Chronic Pain in Male Rats. Iranian Journal of Pharmaceutical Research 3: 185-191.

11. Morito K, Hirose T, Kinjo J, Hirakawa T, Okawa M, et al. (2001) Interaction of phytoestrogens with estrogen receptors alpha and beta. Biol Pharm Bull. 24: 351-356.

12. Muñiz C, Teodosio C, Mayado A, Amaral A, Matarraz S et al. (2015) Ex vivo identification and characterization of a population of $\mathrm{CD}_{13}$ high $\mathrm{CD}_{105}{ }^{+} \mathrm{CD}_{45}$ mesenchymal stem cells in human bone marrow. Stem Cell Research \& Therapy 6: 169.

13. Mark P, Kleinsorge M, Gaebel R, Lux C, Toelk A, et al. (2013) Human Mesenchymal Stem Cells Display Reduced Expression of CD105 after Culture in Serum-Free Medium. Stem Cells International. 98076: 1-8.

14. Park SJ, Kim HJ, Kim W, Kim OS, Lee S, et al. (2016) Tumorigenicity Evaluation of Umbilical Cord Blood-derived Mesenchymal Stem Cells. Toxicological Research 32: 251-258.

15. Lemoli R, Bertolini F, Cancedda R (2005) Stem cell plasticity: time for a reappraisal?. Haematologica. 90: 360-381.

16. Dominici M, Le Blanc K, Mueller I, Slaper-Cortenbach I, Marini F, et al. (2006) Minimal criteria for defining multipotent mesenchymal stromal cells. The International Society for Cellular Therapy position statement. Cytotherapy 8: 315-317.

17. Duf S, Li C, Garland J, Kumar $S$ (2003) $C D_{105}$ is important for angiogenesis: evidence and potential applications. FASEB Journal 17: 984-992.

18. Barresi V, Branca G, Caffo M, Caltabiano R, leni A, et al. (2014) ImmunoExpression of Endoglin and Smooth Muscle Actin in the Vessels of Brain Metastases. Is There a Rational for Anti-Angiogenic Therapy? Int J Mol Sci 15: 5663-5679.

19. Kim W, Park B, Kim H, Park J, Kim K, et al. (2008) Evidence supporting antioxidant action of adipose-derived stem cells: protection of human dermal fibroblasts from oxidative stress. J Dermatol Sci 49: 133-142.

20. Lanza C, Morando S, Voci A, Canesi L, Principato M, etal. (2009) Neuroprotective mesenchymal stem cells are endowed with a potent antioxidant effect in vivo. $J$ Neurochem 110: 1674-1684.

21. Kim Y, Jo S, Kim W, Kweon O (2015) Antioxidant and anti-inflammatory effects of intravenously-injected adipose derived mesenchymal stem cells in dogs with acute spinal cord injury. Stem Cell Res Ther 6: 229.

22. Gawish M, Azmy A, Abdallah M (2006) Effect of protein malnutrition on the liver of prepubertal male albino rats (light and electron microscope study). Z U M J. Special edition pp: 111-133.

23. Kara A, Unal D, Simsek N, Yucel A, Yucel N, et al. (2014) Ultra-structura changes and apoptotic activity in cerebellum of post-menopausal-diabetic rats: a histochemical and ultra-structural study. J Gynecol Endocrinol 30: 226-231.

24. Al-Bazii WJ (2014) Estimation of some oxidative stress parameters in the serum and cerebellum of ovariectomized rats. J Kerbala University 12: 87-94.

25. Latour MG, Shinoda M, Lavoie J (2001) Metabolic effects of physical training in ovariectomized and hyperestrogenic rats. J Applied Physiology 90: 235-241.

26. Peng Y, Jiang B, Wu H, Dai R, Tan $L$ (2012) Effects of genistein on neuronal apoptosis, and expression of $\mathrm{Bcl}-2$ and Bax proteins in the hippocampus of ovariectomized rats. Neural Regen Res 7: 2874-2881.

27. Bieback K, Kern S, Kluter H, Eichler H (2004) Critical parameters for the isolation of mesenchymal stem cells from umbilical cord blood. Stem Cell 22: 625-634.

28. Gómez-Esquer F, Agudo D, Martínez-Arribas F, Nuñez-Villar MJ, Schneider $J$ (2004) mRNA expression ofthe angiogenesis markers VEGF and CD105 (endoglin) in human breast cancer. Anticancer Res. 24: 1581-1585.

29. Tei K, Matsumoto T, Mifune Y, Ishida K, Sasaki K, et al. (2008) Administrations of peripheral blood CD34 - positive cells contribute to medial collateral ligament healing via vasculogenesis. Stem Cells 26: 819-830.
30. Haas SJ, Bauer P, Rolfs A, Wree A (2000) Immunocytochemical characterization of in vitro PKH26-labelled and intracerebrally transplanted neonatal cells. Acta Histochem. 102: 273-280.

31. Calatrava-Ferreras L, Gonzalo-Gobernado F, Herranz A, Reimers D, Vega T, et al. (2012) Effects of Intravenous Administration of Human Umbilical Cord Blood Stem Cells in 3-Acetylpyridine-Lesioned Rats. Stem Cells International pp: 1-14.

32. Bassiouny A, Zaky A, Abdulmalek S, Kandeel K, Ismail A (2011) Modulation of APendonuclease 1 levels associated with hepatic cirrhosis in rat model treated with human umbilical cord blood mononuclear stem cells. Int J Clin Exp Pathol. 4: 692-707.

33. Andreescu C, Milojkovic B, Haasdijk E, Kramer P, De Jong F (2007) Estradio Improves Cerebellar Memory Formation by Activating Estrogen Receptor. Journal of Neuroscience 27: 10832-10839.

34. Boileau C, Martel-Pelletier J, Caron J, Msika P, Guillou G (2009) Protective effects of total fraction of avocado/soybean unsaponifiables on the structural changes in experimental dog osteoarthritis: inhibition of nitric oxide synthase and matrix metalloproteinase-13. Arthritis Res Ther 11: 19-41.

35. Bancroft J, Layton C (2013) The Hematoxylin and eosin. In: Suvarna SK, Layton C and Bancroft JD (ed). Theory and Practice of histological techniques. $7^{\text {th }}$ ed. Churchill Livingstone of El Sevier, Philadelphia, Ch. 10 and 11, pp: 172-214.

36. Ramos-Vara JA, Kiupel M, Baszier T, Bliven L, Brodersen B (2008) Suggested guidelines for immunohistochemical techniques in veterinary diagnostic laboratories. J Vet Diagn Invest 20: 393-413.

37. Nishikimi M, Appaji N, Yagi K (1984) The occurrence of superoxide anion in the reaction of reduced phenazine methosulfate and molecular oxygen. Biochem. Biophys Res Commun 46: 849-854

38. Aebi H (1984) Catalase in vitro. Methods Enzymol 105: 121-126.

39. Beutler F, Duron O, Kelly MB (1963) Improved method of estimation of blood glutathione. J Lab Clin Med 61: 882-890.

40. Mattson MP, Chan SL, Duan W (2002) Modification of brain aging and neurodegenerative disorders by genes, diet and behavior. Physiol Rev 82: 637-672.

41. Chung YH, Shin CM, Joo KM, Kim MJ, Cha Cl (2002) Immunohistochemical study on the distribution of nitrotyrosine and neuronal nitric oxide synthase in aged rat cerebellum. Brain Res 951: 316-321.

42. Gouda S, Naim M, Abd El-Aal H, Mahmoud S (2010) Effect of Alpha-Phenyl-NTert-Butyl Nitrone on Aging of the Cerebellum of Male Albino Rats (Histological and Immunohistochemical Study). Egypt J Histo 33: 495-507.

43. Yao J, Irwin R, Zhao L, Nilsen J, Hamilton R (2009) Mitochondrial bioenergetic deficit precedes Alzheimer's pathology in female mouse model of Alzheimer's disease. Proc Natl Acad Sci 106: 14670-14675.

44. Rocca W, Grossardt B, Shuster L (2010) Oophorectomy, Menopause, estrogen, and cognitive aging: the timing hypothesis. Neurodegener Dis 7: 163-166.

45. Choi JM, Romeo RD, Brake WG, Bethea CL, Rosenwaks Z, et al. (2003) Estradiol increases pre- and post-synaptic proteins in the CA1 region of the hippocampus in female rhesus macaques (Macaca mulatta). Endocrinology 144: 4734-4738.

46. Sasahara K, Shikimi H, Haraguchi S, Sakamoto H, Honda S, et al. (2007) Mode of Action and Functional Significance of Estrogen-Inducing Dendritic Growth, Spinogenesis, and Synaptogenesis in the Developing Purkinje Cell. J Neurosci 27: 7408-7417.

47. Maki P, Resnick S (2001) Effects of estrogen on patterns of brain activity at rest and during cognitive activity: a review of neuroimaging studies. Neuroimage 14: $789-801$.

48. Lopez-Grueso R, Borras C, Gambini J, Viña J (2010) Aging and ovariectomy cause a decrease in brain glucose consumption in vivo in Wistar rats. Review Esp Geriatr Gerontol 45: 136-140.

49. Borrás C, Gambini J, López-Grueso R, Pallardó F, Viña J (2010) Direct antioxidant and protective effect of estradiol on isolated mitochondria Biochimica et Biophysica Acta 1802: 205-211.

50. Sze Cl, Bi H, Kleinschmidt-DeMasters BK, Filley CM, Martin LJ (2000) Selective regional loss of exocytotic presynaptic vesicle proteins in Alzheimer's disease brains. J Neurol Sci 175: 81-90. 
Citation: Ahmed SM, Abdelrahman SA, Shalaby SM (2017) Therapeutic Potential of Mesenchymal Stem Cells vs. Estradiol Benzoate or Avosoya on the Cerebellar Cortex of Ovariectomized Adult Albino Rats. J Cytol Histol 8: 444. doi: 10.4172/2157-7099.1000444

51. Borras C, Gambini J, Gomez-Cabrera M, Sastre J, Pallardo F, et al. (2006) Genistein, a soy isoflavone, up-regulates expression of antioxidant genes: involvement of estrogen receptors, ERK1/2, and NF kappa B. FASEB J 20: $2136-2138$

52. Cendelin J (2016) Experimental neurotransplantation treatment for hereditary cerebellar ataxias. Cerebellum \& Ataxias 3: 3-7.

53. Chen Q, Long Y, Yuan X, Zou L, Sun J, et al. (2005) Protective effects of bone marrow stromal cell transplantation in injured rodent brain: synthesis of neurotrophic factors. J Neurosci Res 80: 611-619.

54. Jones J, Jaramillo-Merchan J, Bueno C, Pastor D, Viso-León M, et al. (2010) Mesenchymal stem cells rescue Purkinje cells and improve motor functions in a mouse model of cerebellar ataxia. Neurobiol Dis. 40: 415-423.

55. Monteiro RA, Henrique RM, Rocha E, Silva MW, Oliveira MH (2000) Quantitative age-changes in endoplasmic reticulum and nucleus of cerebellar granule cells. Neurobiol Aging 21: 97-105.

56. Peinado MA, Martínez M, Ramírez MJ, Quesada A, Pedrosa JA, et al. (2001) Neuromorphological, changes in neuronal and neuroglial population of the cerebral cortex in the aging rat. Neurochemical correlation 12: 3-16.

57. Sofroniew M, Vinters H (2010) Astrocytes: biology and pathology. Acta Neuropathol 119: 7-35.

58. Sakamoto H, Ukena K, Tsutsui K (2001) Effects of progesterone synthesized de novo in the developing Purkinje cell on its dendritic growth and synaptogenesis. J Neurosci 21: 6221-6232.

59. Sakamoto H, Mezaki Y, Shikimi H, Ukena K, Tsutsui K (2003) Dendritic growth and spine formation in response to estrogen in the developing Purkinje cell. Endocrinology 144: 44660-4477.

60. Matsunaga M, Ukena K, Baulieu E, Tsutsui K (2004) 7a-Hydroxypregnenolone acts as a neuronal activator to stimulate locomotor activity of breeding newts by means of the dopaminergic system. Proc Natl Acad Sci USA 101: 1728217287.

61. Al-Sherbini M, Al-Zahrani M, Alrefaie Z, Amin H, Zawawi K (2014) Estrogen deficiency reduces the expression of estrogen receptor-beta in Wistar rats' periodontal tissues. Saudi Med J 35: 242-247.

62. Lephart ED, Setchell KD, Lund TD (2005) Phytoestrogens: hormonal action and brain plasticity. Brain Res Bull 65: 193-198.

63. Adams SM, Aksenova MV, Aksenov MY (2010) ER- $\beta$ mediates $17 \beta$-estradio attenuation of HIV-1 Tat-induced apoptotic signaling. Synapse 64: 829-838.

64. Rossberg MI, Alkayed NJ, Joh HD (2001) Selective estrogen receptor modulator LY353381. $\mathrm{HCl}-$ mediated neuroprotection and $\mathrm{Bcl}-2$ expression after experimental stroke. Stroke 32: 327-333.

65. Dasari V, Veeravalli K, Saving K (2008) Neu-roprotection by cord blood stem cells against glutamate-induced apoptosis is mediated by Akt pathway. Neurobiology of Disease 32: 486-498.

66. Lossi L, Gambino G, Ferrini F, Alasia S, Merighi A (2009) Posttranslational regulation of $\mathrm{Bcl}_{2}$ levels in cerebellar granule cells: a mechanism of neuronal survival. Developmental Neurobiology 69: 855-870.

67. Zhang D, Hu X, Qian L, O'Callaghan J, Hong J (2010) Astrogliosis in CNS pathologies: is there a role for microglia? Molecular Neurobiology 41: 232-241.

68. Aleynik A, Gernavage K, Mourad Y, Sherman L, Liu K, et al (2014) Stem cell delivery of therapies for brain disorders. Clin Transl Med 3: 3-24.

69. Nunomura A, Hofer T, Moreira P, Castellani R, Smith M, et al. (2009) RNA oxidation in Alzheimer disease and related neurodegenerative disorders. Acta Neuropathol 118: 151-166.

70. Behl C, Moosmann B, Manthey D, Heck S (2000) The female sex hormone oestrogen as neuroprotectant: Activities at various levels. Novartis Found Symp 230: 221-234.

71. Borras C, Gambini J, Gomez-Cabrera M, Sastre J, Pallardo F, et al. (2005) $17 \beta$-oestradiol up-regulates longevity-related, antioxidant enzyme expression via the ERK1 and ERK2[MAPK]/NF kappa B cascade. Aging Cell 4: 113-118.

72. Iyer S, Torres-Gonzalez E, Neujahr D, Kwon M, Brigham K, et al. (2010) Effect of bone marrow-derived mesenchymal stem cells on endotoxin-induced oxidation of plasma cysteine and glutathione in mice. Stem Cells Int. 2010: 1-9. 